\title{
GAMBARAN KEJADIAN INFEKSI SALURAN KEMIH PADA IBU HAMIL DI BADAN RUMAH SAKIT UMUM TABANAN
}

\author{
Anak Agung Lidya Nirmala Dewi ${ }^{1}$, Cokorda Dewi Widhya Hana Sundari ${ }^{2}$, \\ Ida Ayu Sri Arjani ${ }^{3}$ \\ 1,2,3 Jurusan Analis Kesehatan Poltekkes Denpasar \\ Email: cokdewi69@yahoo.co.id
}

\begin{abstract}
:
Background: Urinary tract infection (UTI) is an inflammatory reaction of urothelium cells that line the urinary tract due to the proliferation of microorganisms. During pregnancy, dilatation occurs on the ureter and there is a decrease in ureteral peristalsis which increases the risk of bacterial growth.

Objective: The purpose of this study was to determine the incidence of UTI in pregnant women at BRSU Tabanan.

Methods: This study was a descriptive study with population of 160 people and sample of 32 people selected by non-probability sampling technique with accidental sampling method.Examination of respondent's urine sample was done by urine culture with standard loop method.

Results: The result of this study indicate $19 \%$ of pregnant women had calculated colony $>10^{5}$ CFU/ml which can be indicated as UTI.

Conclusion: From the result of the study, it was concluded that the incidence of UTI was most prevalent in pregnant women of the age group 20-35 years, pregnant women in the third trimester of pregnancy, in pregnant women with sexual activity $1 x /$ week, in pregnant women with elementary and high school education, and in pregnant women who change underwear twice or more per day and clean the external urinary tract from the front to the back.
\end{abstract}

Keywords :Urinary Tract Infection (UTI), pregnancy

\section{PENDAHULUAN}

Penyakit infeksi membunuh lebih dari 10 juta penduduk di negara berkembang setiap tahunnya. Banyak diantara mereka meninggal dunia karena kegagalan awal dalam mencegah infeksi atau karena penanganan yang kurang ${ }^{1}$. Suatu infeksi muncul saat mikroorganisme menyebabkan gangguan kesehatan. Hal ini terjadi akibat adanya invasi mikroorganisme pada jaringan pejamu, atau akibat efek yang ditimbulkan mikroorganisme pada permukaan mukosa $^{2}$.

Infeksi organ urogenitalia merupakan salah satu penyakit infeksi

Meditory | ISSN Online : 2549-1520, ISSN Cetak : 2338 - 1159, Vol. 6, No. 1, Juni 2018

HIm. $27-38$, http://ejournal.poltekkes-denpasar.ac.id/index.php/M 
yang sering dijumpai sehari-hari mulai infeksi ringan yang baru diketahui pada saat pemeriksaan urin maupun infeksi berat yang dapat mengancam jiwa. Pada dasarnya infeksi ini dimulai dari infeksi pada saluran kemih (ISK) yang kemudian menjalar menuju organ-organ genitalia bahkan sampai ke ginjal.Infeksi saluran kemih merupakan reaksi inflamasi sel-sel urotelium yang melapisi saluran $\mathrm{kemih}^{3}$. Infeksi saluran kemih akut dibagi dalam dua kategori umum berdasarkan lokasi anatomi yaitu infeksi saluran bawah (uretritis, sistitis, dan prostatitis) dan infeksi saluran atas (pielonefritis akut, abses intrarenal, dan abses perinefrik). Infeksi pada berbagai lokasi ini dapat terjadi bersama atau sendiri dan dapat asimtomatik atau dengan gejala klinis. Beberapa keadaan yang dapat mempengaruhi patogenitas infeksi saluran kemih antara lainjenis kelamin dan aktivitas seksual, sumbatan, disfungsi neurogenik kandung kemih, refluks vesikoureteral, serta kehamilan ${ }^{4}$.

$$
\text { Pada masa kehamilan terjadi }
$$
perubahan anatomi maupun fisiologi saluran kemih yang disebabkan oleh peningkatan kadar hormon progesteron dan obstruksi akibat pembesaran uterus. Terjadi dilatasi ureter terutama pada sisi kanan yang terjadi pada kehamilan tua dan penurunan peristaltik ureter ${ }^{3}$. Obstruksi di sepanjang traktus urinarius ataupun di sebelah distal kandung kemih menyebabkan penumpukan urin, yang merupakan media bagi pertumbuhan bakteri.Obstruksi yang tidak diatasi dapat menimbulkan infeksi atau bahkan menyebabkan gagal ginjal ${ }^{5}$.Komplikasi infeksi saluran kemih pada kehamilan antara lain bakteriuria asimtomatik, sistitis, dan pielonefritis. Bakteriuria asimtomatik dapat menyebabkan komplikasi abortus, bayi lahir prematur dan bayi lahir dengan berat badan rendah, sedangkan pielonefritis dapat menyebabkan kesakitan dan kematian ibu dan janin ${ }^{6}$.

Data Survei Demografi dan Kesehatan Indonesia (SDKI) 2012 menunjukkan bahwa angka kematian bayi selama lima tahun sebelum survei (tahun 2008-2012) adalah 32 kematian per 1.000 kelahiran hidup ${ }^{7}$. Angka kematian bayi khususnya di Provinsi Bali dari tahun 2006 sampai dengan tahun 2015 menunjukkan tren yang fluktuatif, meski sudah lebih rendah dari angka kematian bayi secara nasional. Angka kematian bayi tertinggi terjadi di kabupaten Karangasem yaitu sebesar 10,6/1000 Kelahiran Hidup, angka kematian bayi kedua tertinggi terjadi di

Meditory | ISSN Online : 2549-1520, ISSN Cetak : 2338 - 1159, Vol. 6, No. 1, Juni 2018 
Anak Agung Lidya Nirmala Dewi, dkk., Gambaran Kejadian Infeksi Saluran Kemih pada Ibu Hamil di Badan Rumah Sakit Umum Tabanan

kabupaten Tabanan yaitu sebesar 10,2/1000 Kelahiran Hidup dan angka kematian bayi ketiga tertinggi terjadi di kabupaten Gianyar yaitu sebesar 9,6/1000 Kelahiran Hidup. Permasalahan yang berkaitan dengan kematian bayi di Provinsi Bali didominasi oleh karena Bayi Berat Lahir Rendah (BBLR) dan asfiksia ${ }^{8}$. Hasil penelitian di Kamar Bersalin dan Poli Hamil RSUD Dr. Soetomo didapatkan pada kehamilan dengan ancaman persalinan preterm, $80 \%$ terjadi pertumbuhan kuman. Risiko terjadinya persalinan preterm pada wanita hamil dengan jumlah koloni kuman urin $>10^{5}$ $\mathrm{CFU} / \mathrm{ml} 3$ kali lebih besar dibanding wanita hamil dengan jumlah koloni $<10^{5}$ $\mathrm{CFU} / \mathrm{ml}^{9}$.

\section{METODE}

Jenis penelitian yang digunakan dalam penelitian ini adalah deskriptif. Penelitian dilakukan di BRSU Tabanan dari bulan Januari-Juni 2017 dengan pengujian sampel dilakukan di Laboratorium Bakteriologi Jurusan Analis Kesehatan Poltekkes Denpasar. Populasi penelitian adalah rata-rata jumlah ibu hamil yang berkunjung ke Poliklinik
Kandungan dan Kebidanan di BRSU Tabanan setiap bulannya pada tahun 2016 yang berjumlah 160 orang. Pengambilan sampel dilakukan dengan teknik non probability sampling secara accidental sampling. Menurut Arikunto (2002), apabila jumlah subjek penelitian besar, sampel dapat diambil antara 10-15\% atau 20-25\%. Besar sampel dalam penelitian adalah $20 \%$ dari populasi, sehingga jumlah sampel sebanyak 32 orang ibu hamil ${ }^{10}$. Bahan penelitian adalah urin ibu hamil yang diuji dengan kultur urin metode ose standar. Data yang diperoleh diolah, dan disajikan dalam bentuk tabel-tabel dan membandingkan hasil pemeriksaan infeksi saluran kemih pada ibu hamil dengan teori yang ada.

\section{HASIL DAN PEMBAHASAN}

\section{Hasil}

\section{a. Kejadian infeksi saluran kemih pada ibu hamil di BRSU Tabanan}

Adapun kejadian infeksi saluran kemih pada ibu hamil di BRSU Tabanan seperti pada tabel 1 berikut : 
Tabel 1 Kejadian Infeksi Saluran Kemih pada Ibu Hamil di BRSU Tabanan

\begin{tabular}{cccc}
\hline No. & Uraian & Jumlah & $\%$ \\
\hline 1. & Terindikasi ISK & 6 & 19 \\
2. & Tidak terindikasi ISK & 26 & 81 \\
\hline & Jumlah Total & 32 & 100 \\
\hline
\end{tabular}

Berdasarkan hasil pemeriksaan sampel urin ibu hamil, didapatkan hasil 6 orang (19\%) memiliki nilai hitung koloni bakteri di atas $10^{5} \mathrm{CFU} / \mathrm{ml}$ yang mengindikasikan adanya infeksi saluran kemih pada ibu hamil tersebut, sedangkan 26 orang $(81 \%)$ lainnya memiliki nilai hitung koloni bakteri di bawah $10^{5}$ $\mathrm{CFU} / \mathrm{ml}$ yang menunjukkan tidak adanya infeksi saluran kemih pada ibu hamil tersebut.

b. Kejadian infeksi saluran kemih pada ibu hamil berdasarkan kelompok umur

Kejadian infeksi saluran kemih pada ibu hamil berdasarkan kelompok umur dapat dilihat pada tabel 2 berikut ini.

Tabel 2 Kejadian Infeksi Saluran Kemih pada Ibu Hamil Berdasarkan Kelompok Umur

\begin{tabular}{lcccccc}
\hline Kelompok & \multicolumn{3}{c}{ Kejadian Infeksi Saluran Kemih } & \multicolumn{2}{c}{ Total } \\
\cline { 2 - 6 } Umur Ibu & \multicolumn{2}{c}{ Terindikasi ISK } & \multicolumn{2}{c}{ Tidak terindikasi ISK } & & \\
\cline { 2 - 6 } Hamil & Jumlah & $\%$ & Jumlah & $\%$ & Jumlah & $\%$ \\
\hline$<20$ & 0 & 0 & 0 & 0 & 0 & 0 \\
$20-35$ & 6 & 19 & 23 & 72 & 29 & 91 \\
$>35$ & 0 & 0 & 3 & 9 & 3 & 9 \\
\hline \multicolumn{1}{c}{ Jumlah } & 6 & 19 & 26 & 81 & 32 & 100 \\
\hline
\end{tabular}

Berdasarkan tabel 2 di atas, dari 32 responden yang diteliti, diperoleh data responden yang paling banyak terindikasi ISK yaitu pada kelompok umur20-35 sebanyak 6 orang $(19 \%)$.

\section{c. Kejadian infeksi saluran kemih pada} ibu hamil berdasarkan usia kehamilan

Kejadian infeksi saluran kemih pada ibu hamil berdasarkan usia kehamilan dapat dilihat pada tabel 3 berikut ini.

Meditory | ISSN Online : 2549-1520, ISSN Cetak : 2338 - 1159, Vol. 6, No. 1, Juni 2018 HIm. 27 - 38, http://ejournal.poltekkes-denpasar.ac.id /index.php/M 
Tabel 3 Kejadian Infeksi Saluran Kemih pada Ibu Hamil Berdasarkan Usia Kehamilan

\begin{tabular}{lcccccc}
\hline \multirow{2}{*}{ Usia } & \multicolumn{3}{c}{ Kejadian Infeksi Saluran Kemih } & \multicolumn{2}{c}{ Total } \\
\cline { 2 - 6 } Kehamilan & \multicolumn{2}{c}{ Terindikasi ISK } & \multicolumn{2}{c}{ Tidak terindikasi ISK } & & \\
\cline { 2 - 6 } & Jumlah & $\%$ & Jumlah & $\%$ & Jumlah & $\%$ \\
\hline TM I & 1 & 3 & 1 & 3 & 2 & 6 \\
TM II & 2 & 6 & 1 & 3 & 3 & 9 \\
TM III & 3 & 10 & 24 & 75 & 27 & 85 \\
\hline \multicolumn{1}{c}{ Jumlah } & 6 & 19 & 26 & 81 & 32 & 100 \\
\hline
\end{tabular}

Berdasarkan tabel 3 di atas, dari 32 responden yang diteliti, diperoleh data responden yang paling banyak terindikasi ISK yaitu pada usia kehamilan trimester III sebanyak 3 orang (10\%).

\section{d. Kejadian infeksi saluran kemih pada ibu hamil berdasarkan aktivitas seksual ibu hamil}

Kejadian infeksi saluran kemih pada ibu hamil berdasarkan aktivitas seksual ibu hamil dapat dilihat pada tabel 4 berikut ini.

Tabel 4 Kejadian Infeksi Saluran Kemih pada Ibu Hamil Berdasarkan Aktivitas Seksual Ibu Hamil

\begin{tabular}{ccccccc}
\hline Aktivitas & \multicolumn{3}{c}{ Kejadian Infeksi Saluran Kemih } & \multicolumn{2}{c}{ Total } \\
\cline { 2 - 5 } Seksual Ibu & \multicolumn{2}{c}{ Terindikasi ISK } & \multicolumn{2}{c}{ Tidak terindikasi ISK } & & \\
\cline { 2 - 6 } Hamil & Jumlah & $\%$ & Jumlah & $\%$ & Jumlah & $\%$ \\
\hline 1 x/mgg & 3 & 10 & 14 & 44 & 17 & 53 \\
$1-3 x / m g g$ & 0 & 0 & 7 & 22 & 7 & 22 \\
1 x/bln & 1 & 3 & 1 & 3 & 2 & 6 \\
$1-3 x /$ bln & 2 & 6 & 4 & 12 & 6 & 19 \\
\hline \multicolumn{1}{c}{ Jumlah } & 6 & 19 & 26 & 81 & 32 & 100 \\
\hline
\end{tabular}

Berdasarkan tabel 4 di atas, dari 32 responden yang diteliti, diperoleh data responden yang paling banyak terindikasi ISK yaitu dengan aktivitas seksual 1x/minggu sebanyak 3 orang $(10 \%)$.

\section{e. Kejadian infeksi saluran kemih pada} ibu hamil berdasarkan tingkat pendidikan

Kejadian infeksi saluran kemih pada ibu hamil berdasarkan tingkat pendidikan ibu hamil dapat dilihat pada tabel 5 berikut ini.

Meditory | ISSN Online : 2549-1520, ISSN Cetak : 2338 - 1159, Vol. 6, No. 1, Juni 2018 HIm. $27-38$, http://ejournal.poltekkes-denpasar.ac.id/index.php/M 
Tabel 5 Kejadian Infeksi Saluran Kemih pada Ibu Hamil Berdasarkan Tingkat Pendidikan

\begin{tabular}{lcccccc}
\hline \multirow{2}{*}{$\begin{array}{c}\text { Tingkat } \\
\text { Pendidikan }\end{array}$} & \multicolumn{3}{c}{ Kejadian Infeksi Saluran Kemih } & \multicolumn{2}{c}{ Total } \\
\cline { 2 - 5 } & \multicolumn{2}{c}{ Terindikasi ISK } & \multicolumn{2}{c}{ Tidak terindikasi ISK } & & \\
\cline { 2 - 6 } & Jumlah & $\%$ & Jumlah & $\%$ & Jumlah & $\%$ \\
\hline SD & 2 & 6,5 & 3 & 9 & 5 & 15,5 \\
SMP & 1 & 3 & 3 & 9 & 4 & 12 \\
SMA & 2 & 6,5 & 16 & 50 & 18 & 56,5 \\
$\begin{array}{l}\text { Perguruan } \\
\text { tinggi }\end{array}$ & 1 & 3 & 4 & 13 & 5 & 16 \\
\hline \multicolumn{1}{c}{ Jumlah } & 6 & 19 & 26 & 81 & 32 & 100 \\
\hline
\end{tabular}

Berdasarkan tabel 5 di atas, dari 32 responden yang diteliti, diperoleh data responden yang paling banyak terindikasi ISK yaitu pada tingkat pendidikan SD dan SMA sebanyak 2 orang $(6,5 \%)$.

\section{f. Kejadian infeksi saluran kemih pada ibu hamil berdasarkan higiene perorangan}

Tabel 6 Kejadian Infeksi Saluran Kemih Pada Ibu Hamil Berdasarkan Kebiasaan Mengganti Pakaian Dalam

\begin{tabular}{lcccccc}
\hline \multirow{2}{*}{ Higiene Perorangan } & \multicolumn{3}{c}{ Kejadian Infeksi Saluran Kemih } & & \multicolumn{2}{c}{ Total } \\
\cline { 2 - 6 } & \multicolumn{2}{c}{ Terindikasi ISK } & \multicolumn{2}{c}{ Tidak terindikasi ISK } & & \\
\cline { 2 - 6 } & Jumlah & $\%$ & Jumlah & $\%$ & Jumlah & $\%$ \\
\hline $\begin{array}{l}\text { Mengganti pakaian } \\
\text { dalam 1 kali dalam } \\
\text { sehari }\end{array}$ & 2 & 6 & 0 & 0 & 2 & 6 \\
$\begin{array}{l}\text { Mengganti pakaian } \\
\text { dalam 2 kali atau } \\
\text { lebih dalam sehari }\end{array}$ & 4 & 13 & 26 & 81 & 30 & 94 \\
\hline \multicolumn{1}{c}{ Jumlah } & 6 & 19 & 26 & 81 & 32 & 100 \\
\hline
\end{tabular}

Berdasarkan tabel 6 di atas, dari 32 mengganti pakaian dalam 2 kali atau lebih responden yang diteliti, diperoleh data dalam sehari sebanyak 4 orang (13\%). responden yang paling banyak terindikasi ISK yaitu responden dengan kebiasaan Meditory | ISSN Online : 2549-1520, ISSN Cetak : 2338 - 1159, Vol. 6, No. 1, Juni 2018 HIm. $27-38$, http://ejournal.poltekkes-denpasar.ac.id/index.php/M 
2) Kejadian infeksi saluran kemih pada ibu hamil berdasarkan kebiasaan membersihkan saluran kemih bagian luar
Kejadian infeksi saluran kemih pada ibu hamil berdasarkan kebiasaan ibu hamil membersihkan saluran kemih bagian luar dapat dilihat pada tabel 7 berikut ini.

Tabel 7 Kejadian Infeksi Saluran Kemih pada Ibu Hamil Berdasarkan Kebiasaan Membersihkan Saluran Kemih Bagian Luar

\begin{tabular}{lcccccc}
\hline \multirow{2}{*}{ Higiene Perorangan } & \multicolumn{3}{c}{ Kejadian Infeksi Saluran Kemih } & \multicolumn{2}{c}{ Total } \\
\cline { 2 - 6 } & \multicolumn{2}{c}{ Terindikasi ISK } & \multicolumn{2}{c}{ Tidak terindikasi ISK } & & \\
\cline { 2 - 6 } & Jumlah & $\%$ & Jumlah & $\%$ & Jumlah & $\%$ \\
\hline $\begin{array}{l}\text { Membersihkan dari } \\
\text { arah depan ke }\end{array}$ & 5 & 16 & 26 & 81 & 31 & 97 \\
$\begin{array}{l}\text { belakang } \\
\begin{array}{l}\text { Membersihkan dari } \\
\text { arah belakang ke } \\
\text { depan }\end{array}\end{array}$ & 1 & 3 & 0 & 0 & 1 & 3 \\
\hline \multicolumn{1}{c}{ Jumlah } & 6 & 19 & 26 & 81 & 32 & 100 \\
\hline
\end{tabular}

Berdasarkan tabel 7 di atas, dari 32 responden yang diteliti, diperoleh data responden yang paling banyak terindikasi ISK yaitu responden dengan kebiasaan membersihkan saluran kemih bagian luar dari arah depan ke belakang sebanyak 5 orang (16\%).

\section{Pembahasan}

Infeksi saluran kemih (ISK) adalah infeksi yang terjadi di sepanjang saluran kemih termasuk ginjal itu sendiri, akibat proliferasi suatu mikroorganisme. Sebagian besar infeksi saluran kemih disebabkan oleh bakteri, tetapi jamur dan virus juga dapat menjadi penyebabnya. Infeksi bakteri paling sering disebabkan oleh Escherichia coli ${ }^{11}$. Secara mikrobiologis, dikatakan infeksi saluran kemih jika ditemukan mikroorganisme patogen dalam urin, uretra, kandung kemih, ginjal, atau prostat. Beberapa keadaan yang dapat mempengaruhi patogenitas infeksi saluran kemih antara lain jenis kelamin dan aktivitas seksual, sumbatan, disfungsi neurogenik kandung kemih, refluks vesikoureteral, serta kehamilan ${ }^{4}$.

Penelitian kejadian infeksi saluran kemih pada ibu hamil di BRSU Tabanan telah dilakukan terhadap 32 responden. Berdasarkan hasil pemeriksaan urin pancar tengah responden, didapatkan hasil yaitu 6 orang (19\%) dari 32 responden memiliki

Meditory | ISSN Online : 2549-1520, ISSN Cetak : 2338 - 1159, Vol. 6, No. 1, Juni 2018

HIm. 27 - 38, http://ejournal.poltekkes-denpasar.ac.id/index.php/M 
nilai hitung koloni $>10^{5} \mathrm{CFU} / \mathrm{ml}$. Adanya pertumbuhan bakteri $>10^{5} \quad \mathrm{CFU} / \mathrm{ml}$ mengindikasikan adanya infeksi saluran kemih. Berdasarkan hasil wawancara, dari 6 orang yang terindikasi adanya infeksi saluran kemih, 2 orang diantaranya memiliki gejala berupa nyeri di bagian bawah perut dan terus menerus ingin buang air kecil, sementara 4 orang lainnya tidak memiliki gejala atau keluhan tertentu.

\section{Menurut Badan Koordinasi} Keluarga Berencana Nasional (2007), umur ibu hamil yang terlalu muda adalah $<20$ tahun dan yang terlalu tua adalah $>35$ tahun $^{12}$. Berdasarkan kelompok umur, dapat diketahui bahwa keseluruhan ibu hamil yang terindikasi ISK pada penelitian ini yaitu sejumlah 19\% berada pada kelompok umur 20-35 tahun.Hasil ini dapat dikarenakan jumlah responden ibu hamil yang tidak terdistribusi secara merata pada setiap kelompok umur (Tabel 2), sehingga dalam penelitian ini kejadian ISK seluruhnya terjadi pada kelompok umur tidak berisiko yaitu 20-35 tahun.

Berdasarkan usia kehamilan, diperoleh data responden yang paling banyak terindikasi ISK adalah pada usia kehamilan trimester III sebanyak 3 orang (10\%), kemudian pada usia kehamilan trimester II sebanyak 2 orang (6\%) dan pada usia kehamilan trimester I sebanyak 1 orang (3\%). Dalam penelitian ini belum dapat disimpulkan terjadi peningkatan kejadian ISK seiring dengan peningkatan usia kehamilan. Hal ini dikarenakan distribusi jumlah responden ibu hamil tidak tersebar secara merata pada setiap kelompok usia kehamilan (Tabel 3), sehingga secara jumlah responden maka akan ditemukan kejadian ISK tentunya paling banyak pada usia kehamilan trimester III. Walaupun pada penelitian ini, didapatkan bahwa angka kejadian ISK paling banyak terjadi pada usia kehamilan trimester III, namun semua perempuan hamil harus diperiksa adanya bakteriuria tanpa gejala selama trimester pertama ${ }^{4}$.

Uretra wanita berukuran lebih pendek sehingga bakteri kontaminan lebih mudah memperoleh akses ke kandung kemih, selain itu, kecenderungan terjadinya iritasi kulit lubang uretra pada perempuan saat melakukan hubungan seksual juga meningkatkan risiko infeksi saluran kemih pada perempuan ${ }^{11}$. Berdasarkan aktivitas seksual ibu hamil, diperoleh data responden yang paling banyak terindikasi ISK yaitu dengan aktivitas seksual 1x/minggu sebanyak $10 \%$, kemudian sebanyak $6 \%$ dengan 
aktivitas seksual 1-3x/bulan dan 3\% dengan aktivitas seksual 1x/bulan. Hasil ini belum dapat menunjukkan adanya peningkatan kejadian ISK seiring dengan peningkatan aktivitas seksual ibu hamil karena pada frekuensi aktivitas seksual paling sering yaitu 1-3x/minggu justru tidak ditemukan kejadian ISK. Selain itu, pada penelitian ini distribusi responden pada setiap frekuensi aktivitas seksual juga tidak merata (Tabel 4). Dari perbandingan jumlah responden tersebut maka kejadian ISK cenderung lebih banyak ditemukan pada ibu hamil dengan aktivitas seksual 1x/minggu.

Dalam penelitian yang dilakukan Pradono dan Sulistyowati tentang Hubungan Antara Tingkat Pendidikan, Pengetahuan Tentang Kesehatan Lingkungan, Perilaku Hidup Sehat Dengan Status Kesehatan di Jakarta Pusat didapatkan bahwa ada hubungan yang positif dan sangat signifikan antara tingkat pendidikan dengan status kesehatan responden $^{13}$. Berdasarkan tingkat pendidikan, diperoleh data responden yang paling banyak terindikasi ISK yaitu pada tingkat pendidikan SD dan SMA sebanyak masing-masing 2 orang (6,5\%), sedangkan pada tingkat pendidikan SMP dan perguruan tinggi didapatkan masing- masing 1 orang (3\%). Hasil ini dapat dikarenakan distribusi responden pada setiap tingkat pendidikan tidak merata (Tabel 5), sehingga dari jumlah responden tersebut maka akan cenderung banyak ditemukan kejadian ISK pada ibu hamil dengan tingkat pendidikan SMA.

Etiologi infeksi saluran kemih pada ibu hamil salah satunya adalah kebiasaan higiene yang buruk seperti tidak cukup bersih membilas atau mengganti pakaian dalam atau pembalut sehingga menyebabkan bakteri menghampiri uretra untuk memperbanyak diri, dan mengusap dari belakang ke depan sehingga bakteri masuk dari rektum ke uretra ${ }^{14}$. Berdasarkan higiene perorangan ibu hamil, dari 32 responden yang diteliti, diperoleh data 2 orang terindikasi ISK dari total 2 orang yang mengganti pakaian dalam 1 kali sehari, dan diperoleh 4 orang terindikasi ISK dari total 30 orang yang mengganti pakaian dalam 2 kali atau lebih dalam sehari. Berdasarkan tabel 14, dari 32 responden yang diteliti, diperoleh data satu orang terindikasi ISK dari total 1 orang yang memiliki kebiasaan membersihkan saluran kemih bagian luar dari arah belakang ke depan, dan diperoleh 5 orang terindikasi ISK dari total 31 orang yang memiliki kebiasaan membersihkan

Meditory | ISSN Online : 2549-1520, ISSN Cetak : 2338 - 1159, Vol. 6, No. 1, Juni 2018 
saluran kemih bagian luar dari arah depan ke belakang. Hasil penelitian ini menunjukkan bahwa kejadian ISK paling banyak ditemukan pada ibu hamil dengan kebiasaan higiene yang baik yaitu mengganti pakaian dalam 2 kali sehari dan membersihkan saluran kemih bagian luar dari arah depan ke belakang. Hal ini dapat dikarenakan distribusi responden pada masing-masing kebiasaan yang tidak tersebar secara merata (Tabel 6 dan 7). Namun demikian, tiga orang responden dengan kebiasaan higiene perorangan yang buruk seluruhnya terindikasi ISK. Adapun 3 orang lainnya yang memiliki kebiasaan higiene perorangan yang baik dapat terindikasi ISK karena dipengaruhi faktorfaktor lainnya seperti salah satunya aktivitas seksual. Kejadian ISK yang lebih tinggi pada kelompok ibu hamil dengan higiene perorangan yang baik pada penelitian ini dapat menggambarkan bahwa ibu hamil dengan higiene perorangan yang baik masih memiliki kemungkinan mengalami ISK.

\section{SIMPULAN DAN SARAN}

\section{Simpulan}

Hasil pemeriksaan terhadap adanya indikasi infeksi saluran kemih pada 32 orang ibu hamil menunjukkan hasil 19\% memiliki hasil hitung koloni $>10^{5} \mathrm{CFU} / \mathrm{ml}$ yang mengindikasikan adanya infeksi saluran kemih, sedangkan $81 \%$ memiliki nilai hitung koloni $<10^{5} \mathrm{CFU} / \mathrm{ml}$ yang tidak mengindikasikan adanya infeksi saluran kemih.

Kejadian infeksi saluran kemih berdasarkan kelompok umur paling banyak terjadi pada ibu hamil dengan kelompok umur 20-35, berdasarkan usia kehamilan yaitu pada ibu hamil dengan usia kehamilan trimester III, berdasarkan aktivitas seksual yaitu pada ibu hamil dengan frekuensi aktivitas seksual 1x/minggu, berdasarkan tin๕ 36 pendidikan yaitu pada ibu hamil den ${ }_{0} . .$. tingkat pendidikan SD dan SMA, berdasarkan kebiasaan mengganti pakaian dalam yaitu pada ibu hamil dengan kebiasaan mengganti pakaian dalam 2 kali atau lebih dalam sehari, dan berdasarkan kebiasaan membersihkan saluran kemih bagian luar yaitu pada ibu hamil yang membersihkan saluran kemih bagian luar dari arah depan ke belakang.

\section{Saran}

$$
\text { Bagi ibu hamil disarankan }
$$
melakukan pemeriksaan kultur urin pada trimester I untuk mengetahui adanya indikasi infeksi saluran kemih yang tidak menimbulkan gejala atau yang disebut bakteriuria asimtomatik dan 
memperhatikan higiene organ saluran kemih untuk mencegah terjadinya ISK selama kehamilan. Bagi peneliti selanjutnya, agar dapat melakukan penelitian lebih lanjut mengenai faktorfaktor risiko infeksi saluran kemih pada ibu hamil serta dapat mengidentifikasi bakteri penyebab infeksi saluran kemih pada ibu hamil.

\section{DAFTAR PUSTAKA}

1. Mitchell, R.N., Vinay Kumar, Abul K. Abbas, dan Nelson Fausto, 2009, Buku Saku Dasar Patologis Penyakit, Alih Bahasa : Andry Hartono, Penerbit Buku Kedokteran EGC, Jakarta.

2. Gillespie S.H. dan Kathleen B. Bamford, 2009, At a Glance Mikrobiologi Medis dan Infeksi. Alih Bahasa : Stella Tinia H, Penerbit Erlangga, Jakarta.

3. Purnomo, B.B. 2003. Dasar-dasar Urologi Edisi Keduahttps://www.scribd.com/doc/188 520814/Dasar-Dasar-Urologi Diakses Minggu, 27 November 2016.

4. Isselbacher, K.J., Eugene Braunwald, Jean D. Wilson, Joseph B. Martin, Anthony S.Fauci, dan Dennis L.Kasper. 2014. Prinsip-prinsip Ilmu Penyakit Dalam Volume 2 Edisi 13. Alih Bahasa : Andry Hartono et al. Jakarta : Penerbit Buku Kedokteran EGC

5. Kowalak, J.P., William Welsh, dan Brenna Mayer. 2012. Buku Ajar Patofisiologi. Alih Bahasa: Andry Hartono. Jakarta : Penerbit Buku Kedokteran EGC

6. Boekitwetan, P. 2000, Komplikasi Bakteriuria pada Kehamilan. $J$
Kedokter Trisakti 2000. 19(3) : 89-95

http://www.univmed.org/wpcontent/uploads/2011/02/Vol.19_no.3_ 1.pdf Diakses Rabu, 23 November 2016.

7. Badan Kependudukan dan Keluarga Berencana Nasional. 2013, Survei Demografi dan Kesehatan Indonesia tahun 2012. http://chnrl.org/pelatihandemografi/SDKI-2012.pdf Diakses Minggu, 27 November 2016.

8. Dinas Kesehatan Provinsi Bali. 2016. Profil Kesehatan Provinsi Bali tahun 2015.

http://www.diskes.baliprov.go.id/files/ subdomain/diskes/Profil\%20Kesehatan \%20Provinsi\%20Bali/Tahun\%202015/ Bali_Profil_2015.pdf Diakses Jumat, 25 November 2016.

9. Masteryanto, H.M., Gatut Hardianto, Hermanto Tri Joewono, dan Eko Budi Koendhori. 2015. Infeksi Saluran Kemih Sebagai Faktor Risiko Terjadinya Ancaman Persalinan Preterm. Majalah Obstetri \& Ginekologi. 23(2) : 75-81. http://ejournal.unair.ac.id/index.php/MOG/arti cle/view/2093 Diakses Minggu, 19 Pebruari 2017

10. Arikunto, S. 2002. Prosedur Penelitian. Edisi Revisi V. Jakarta : PT Rineka Cipta

11. Corwin, E.J. 2009. Buku Saku Patofisiologi. Alih Bahasa : Nike Budhi Subekti. Jakarta : Penerbit Buku Kedokteran EGC

12. Badan Koordinasi Keluarga Berencana Nasional. 2007. Hindari Kehamilan "4 Terlalu".

http://nad.bkkbn.go.id/data/Documents 14\%20terlalu.pdf Diakses Kamis, 15 Juni 2017

13. Pradono, J dan Sulistyowati, N. 2014. Hubungan Antara Tingkat Pendidikan, Pengetahuan Tentang Kesehatan Lingkungan, Perilaku Hidup Sehat

Meditory | ISSN Online : 2549-1520, ISSN Cetak : 2338 - 1159, Vol. 6, No. 1, Juni 2018 HIm. $27-38$, http://ejournal.poltekkes-denpasar.ac.id/index.php/M 
Anak Agung Lidya Nirmala Dewi, dkk., Gambaran Kejadian Infeksi Saluran Kemih pada Ibu Hamil di Badan Rumah Sakit Umum Tabanan

Dengan Status Kesehatan. Buletin

Penelitian Sistem Kesehatan. 17(1)

:89-95.

https://media.neliti.com/media/publicat

ions/20885-ID-correlation-between-

education-level-knowledge-of-

environmental-health-healthy-

be.pdf.Diakses Senin, 19 Juni 2017

14. Morgan, G. dan Carole Hamilton. 2009. Obstetri \& Ginekologi. Alih Bahasa : Rusi M. Syamsi dan Ramona P. Kapoh. Jakarta : Penerbit Buku Kedokteran EGC

Meditory | ISSN Online : 2549-1520, ISSN Cetak : 2338 - 1159, Vol. 6, No. 1, Juni 2018 HIm. $27-38$, http://ejournal.poltekkes-denpasar.ac.id/index.php/M 